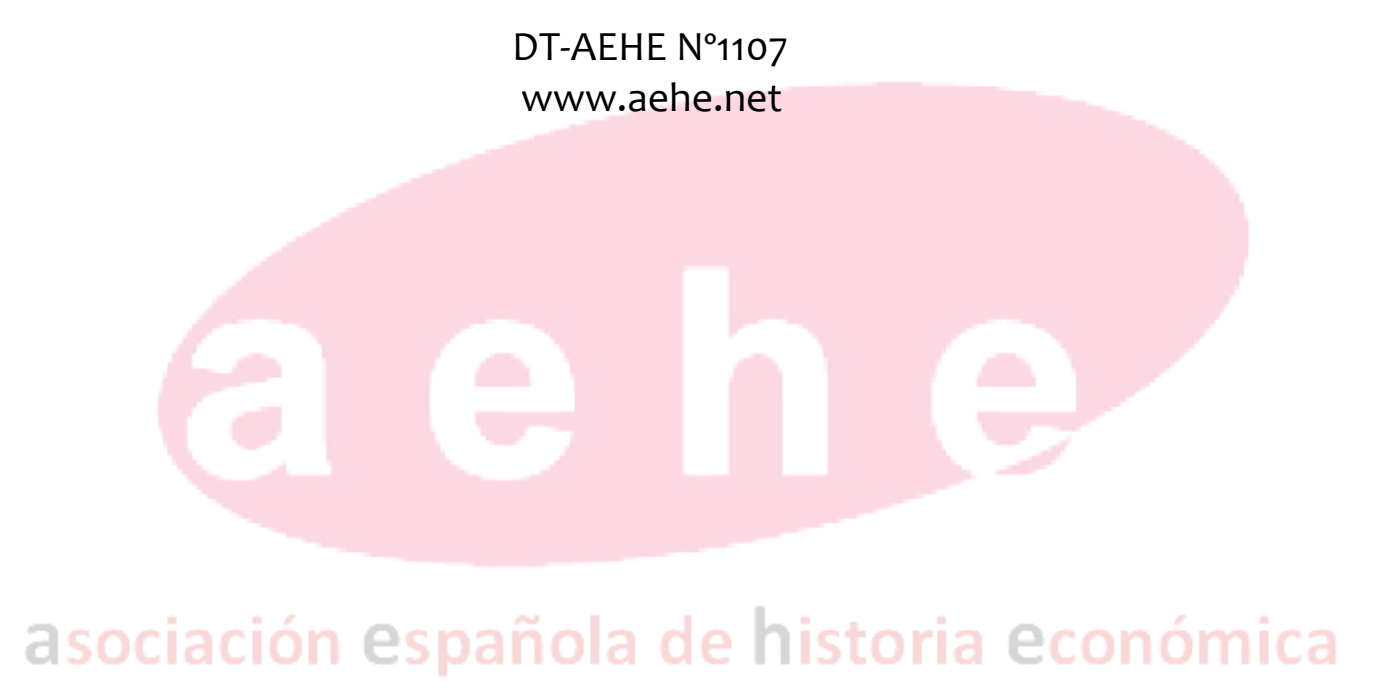

September 2011

\footnotetext{
$\propto(\mathrm{cc})$ BY-NC-ND This paper is protected by a a Creative Commons licence: AttributionNonCommercial- NonDerivativeWork. The details of the licence can be consulted here: http://creativecommons.org/licenses/by-nc-nd/3.o/deed.en.
} 


\title{
NOT ONLY SUBTERRANEAN FORESTS: WOOD CONSUMPTION AND ECONOMIC DEVELOPMENT IN BRITAIN (1850-1938)
}

Iñaki Iriarte-Goñi ${ }^{+}$and $M^{a}$ Isabel Ayuda *

AEHE DT-1107, September 2011

JEL: C22, N53, N54, O13, Q21

\begin{abstract}
The essential aim of this paper is to analyze wood consumption in Great Britain over the period 1850-1938. We calculate the apparent consumption of wood in Britain, taking into account both net imports of wood and the home harvest of wood. Then we develop some quantitative exercises which correlate wood consumption with GDP, and with prices of wood and iron (as an alternative material to wood). The main conclusion is that, although wood had lost its economic centrality after the energetic transition, wood consumption continued to grow in Britain both in absolute and relative terms, showing a positive elasticity to GDP superior to the unity. The decline of wood prices in the long run, the innovations affecting wood exploitation and treatment, and the fact that wood was used in a wide range of economic activities, can explain that growth in consumption. Britain faced the increase in wood demand relying almost totally on imports. Thus, although British economic development was to a great extent focussed on what has been called the "subterranean forests" of coal, simultaneously supported large tracts of foreign forest.
\end{abstract}

Keywords: wood, forest history, industrialization, consumption function

\section{RESUMEN}

El objetivo de este trabajo es analizar el consumo británico de madera en el periodo 1850-1938. En él calculamos el consumo aparente de madera tomando en consideración tanto las importaciones netas como la producción doméstica de madera. Partiendo de esa medición, desarrollamos algunos ejercicios cuantitativos que ponen en relación el consumo de madera con el PIB y con los precios de la madera y del hierro (como material alternativo). La principal conclusión es que aunque la madera había perdido su centralidad económica tras la transición energética, su consumo continuó creciendo en términos tanto absolutos como relativos, mostrando una elasticidad positiva y superior a la unidad respecto al PIB. La caída de los precios de la madera en el largo plazo, las innovaciones que afectaron a la explotación y al tratamiento de la madera, así como el hecho de que la madera fuera utilizada en una amplia gama de actividades, pueden explicar el aumento del consumo. Gran Bretaña hizo frente al incremento del consumo basándose casi en exclusiva en las importaciones. Así, aunque el crecimiento económico británico se basó en gran medida en los denominados "bosques subterráneos" de carbón, necesitó al mismo tiempo recurrir a una gran cantidad de bosques extranjeros

Palabras clave: bosque, historia del bosque, industrialización, función de consumo

\footnotetext{
+ Department of Applied Economics and Economic History, Faculty of Economics. Gran Vía 4, (50005) Zaragoza, Spain. Email: iiriarte@unizar.es. Tel.: 34976 761784. Fax.: 34976761840.

* Department of Economic Analysis, Faculty of Economics. Gran Vía 4, (50005) Zaragoza, Spain. Email: mayuda@unizar.es.Tel.: 34976 762410.Fax.: 34976761996
} 


\section{Not only subterranean forests: Wood consumption and economic development in Britain (1850-1938)}

\section{Introduction}

Although, as is evident, the forest is much more than a storehouse of timber, wood has been -and to a significant extent continues to be- the main economic product obtained from forests. Therefore, the evolution of wood use throughout history can provide interesting keys to a better understanding of the criteria and the specific ways in which forests have been exploited. As is well known, the economic uses of wood changed radically as industrialization spread throughout the western world. In Early Modern Europe, wood was a key element of the economy, since it was the main source of energy for daily life and for the operation of many industries. It was also the essential raw material in the manufacture of many products. As Warde (2006a) has pointed out, wood can be considered, at that moment, as an "avenue to understanding much of the needs, tensions, conflicts and attitudes of the day". With industrialization, new materials and sources of energy, in the form of fossil fuels, entered the economic system, diminishing the importance of organic raw materials (Wrigley, 1988; 2010). It was one of the main elements of a process that has been described by some authors as the change in the social metabolism of economies (Fischer-Kowalski and Haberl, 1993; Krausmann, Schandl, and Schulz, 2003). From then on, energy came from what has been called the "subterranean forests" of coal (Sieferle, 2001), through which modern economies were decoupled from the supply of energy coming from the surface of the land (Kraussman, Schandl and Sieferle, 2008).

Nevertheless, do those changes mean that wood consumption declined with industrialization? Could we thus speak of a wood dematerialization associated with modern industrial growth? Was industrialization just a matter of subterranean forest? In a previous work (Iriarte-Goñi and Ayuda, 2008) we analyzed the evolution of wood consumption in Spain throughout the first and second industrial revolutions, discovering two salient facts. On the one hand, the importance of wood in relation to GDP tended to decrease (through the decline in firewood consumption); but on the other hand, the total consumption of wood continued to increase (for the increase of wood used as a raw material) and the elasticity of wood (with respect to GDP) as a raw material had a positive sign. Consequently, the economic pressure on forests also increased, as industrialization continued to develop in Spain.

The basic objective of this paper is to revisit that topic for the British case, to see whether or not the most developed economy in the world during the 19th century followed a tendency similar to that of the Spanish case. Our starting hypothesis is that, far from producing a wood dematerialization process, British economic growth from 1850 to 1938 required increased quantities of wood coming from foreign forests. From this perspective, the British industrialization process not only was a question of subterranean forest, but also a question of forest being exploited abroad. 
In Section 2 of the present paper, we calculate the apparent consumption of wood in Britain, taking into account both net imports of wood (Section 2.a) and the home harvest of timber (Section 2.b). In Section 3, we develop some quantitative exercises which correlate wood consumption with GDP, and with prices of wood and iron (as an alternative material to wood) and with other magnitudes. In section 4, we discuss the effects of economic growth on the use of wood, the forces driving the substitution - or not - of this material, and the effects of technological change applied to wood itself. The paper finishes with the concluding remarks.

\section{An estimation of British wood and timber consumption}

British Statistical Abstracts do not include annual data on timber consumption until the 1940s. Before that date, one way to approximate that magnitude is to calculate "apparent consumption" following the formula: consumption = timber imports, minus timber exports, plus home-grown wood and timber, and thus the objective of this part of the work is to construct reliable series of net imports and of home-grown timber.

\section{2. a) The evolution of net imports}

As Statistical Abstracts collect imports and exports from the middle of the $19^{\text {th }}$ century, the calculation of annual net imports is a relatively easy task ${ }^{1}$. Table 1 shows the evolution, in cubic meters, of the British international trade in wood between 1850 and 1939.

\section{TABLE 1}

\section{BRITISH WOOD IMPORTS AND EXPORTS}

(Annual averages in cubic meters for each period)

$\begin{array}{lrrrrrrr} & 1850-1854 & 1886-1890 & 1909-1913 & 1915-1919 & 1925-1930 & 1934-1938 \\ \text { Wood imports } & 3252841 & 9459218 & 13852370 & 6778186 & 16772938 & 17408835 \\ (1909-13=100) & 23 & 68 & 100 & 49 & 121 & 126 \\ \text { Pulpwood imports } & & 709476 & 5371569 & 4171053 & 10438071 & 12825273 \\ (1909-13=100) & & 13 & 100 & 78 & 194 & 239 \\ \text { Total imports } & 3252841 & 10168694 & 19223939 & 10949238 & 27211009 & 30234108 \\ (1909-13=100) & 17 & 53 & 100 & 57 & 142 & 157 \\ \text { Wood exports } & 2009 & 70609 & 120475 & 40576 & 56389 & 9262 \\ (1909-13=100) & 17 & 59 & 100 & 34 & 47 & 8 \\ \text { Cover index } & 0.62 & 0.69 & 0.63 & 0.37 & 0.21 & 0.03 \\ & & & & & & \\ \text { Net imports } & 3232749 & 10098086 & 19103463 & 10908662 & 27154621 & 30224846 \\ (1909-13=100) & 17 & 53 & 100 & 57 & 142 & 158\end{array}$

The tradition of importing wood for the British economy dates back to the Early Modern Era and addresses the relative scarcity of woodlands in the interior of the country, as well as the ease of obtaining this commodity from other countries through commercial exchanges. On the one hand, the favorable agricultural conditions of the

\footnotetext{
${ }^{1}$ The transformation of original magnitudes from the source to cubic meters, has been done following ratios provided by Zapata (2001).
} 
British economy, together with a growing urban demand for food, produced an agricultural revolution resulting in an expansion of cultivated lands and pasture. This contributed to the considerable reduction of woodlands (Allen, 2009). The early energy transition of the British economy and the reduced dependence on wood as an energy source had a similar effect. On the other hand, the expansion of commercial relationships in the North Sea and the Baltic facilitated obtaining good quality wood that grew near the coasts and that, could provide a significant part of British consumption (Astrom, 1987). According to provisional statistics from Warde (2010), imported wood already represented a $40 \%$ of British consumption during the $17^{\text {th }}$ century. This tendency was reinforced throughout the $18^{\text {th }}$ century; as colonial expansion took place, British Columbia became the main provider of wood to Great Britain, especially at the beginning of the 19th centuries. This was aided by the differential tariffs that made Canadian wood more accessible than that from the Baltic. This situation changed from the $1840 \mathrm{~s}$, as Great Britain reduced its timber duties - a reduction that has been considered the "silent partner of the corn laws" (Albion, 1926; Potter, 1955) and that completely liberalized timber in the British market from 1866 on.

From the middle of the $19^{\text {th }}$ century, imports grew, becoming the main source of wood for the British market. In fact, as is explained later, the capacity of the British economy to expand its home-grown timber was practically non-existent, at least until the 1920s, while imports continued to grow. This behavior can be explained as much by the lack of development of English forestry as by the growth of a network of wellconnected importers in international markets. In addition, these importers became organized at the end of the $19^{\text {th }}$ century as The Timber Trade Federation, facilitating the defense of their interests in the domestic as well as in the international markets (Fitzgerald and Grenier, 1992). To that must be added the increase of the supply of wood in international markets from areas such as Sweden in the last decades of the $19^{\text {th }}$ century (Söderlund, 1953; Gaunitz, 1969) and Russia in the first decades of the 20th century (Latham, 1957; Stebbing, 1919), as those countries modernized their economies. The decrease in freight rates was also significant. As Dyos and Aldcroft (1969) have pointed out, the revolution in transportation at the end of the 19th century made the relationship between weight and external value less important in commercial transactions, and had a positive effect on the traffic of products such as wood, whose value relative to its volume was very low.

In parallel, another advantage that timber imports had for British companies was that these imports concentrated the places where it was possible to acquire this raw material. This is one of the advantages that Wrigley (2010) granted to coal with regard to that of firewood: while the obtaining of firewood was "areal" and required the use of a broad expanse of land to obtain energy, coal production was "punctiform" and, consequently could be obtained in abundant quantities from one point (the colliery), with the corresponding reduction of transport costs. This same rationale could be applied to national vs. imported wood. While the former had to be obtained from extensive forested areas, the latter arrived concentrated, at ports of import, facilitating its distribution to individuals and companies. Obviously, that wood had been obtained from extensive areas abroad, but the cost of harvesting it and sending it to ports of departure was borne by foreign producers, while British companies found it already gathered at unloading points at competitive prices. 
Thus, the advantages that imports represented for British consumption of wood were many, which explains its behavior from the middle of the $19^{\text {th }}$ century. As table 1 shows, imports of solid wood continued to grow from 1850 until the First World War. During the war, imports were considerably restricted due to the embargo which Great Britain underwent, and also to the necessity to use available ships for the importation of other goods that were more crucial for the economy in time of war. After the war, the imports continued to grow during the 1920s until they surpassed 1913 levels. They continued growing during the $1930 \mathrm{~s}$, although at a more moderate rate. Also, from the decade of the 1880s, the use of wood pulp for paper significantly increased the foreign purchase of that product. In fact, its imports grew at a more rapid rate than that of solid wood before the World War, declined less during wartime, and recovered more strongly during the $1920 \mathrm{~s}$ and especially the 1930s. Table 1 also shows that practically all imported wood was consumed by the British economy. Only a small amount, around $0.65 \%$ of imported wood during the second half of the 19th century, was sold abroad. The majority of those sales were re-exports of wood coming from British colonies and their percentage declined until it practically disappeared in the 1930s.

In short, the case of wood fits well with the commercial behavior of Great Britain during the period considered. In the same way as with other raw materials and food, the British economy was able to acquire those products from foreign sources thanks to commercial revenue obtained by the export of manufactured products. Thus, it is worth emphasizing that combined imports of wood and wood pulp represented a fairly stable percentage of the total value of British imports, remaining around 6.5\% from 1850 until 1913, and falling to around 5\% during the inter-War years.

\section{2.b) An estimation of home-grown timber}

As many works on the problem have stated (e.g. Jefferies, 1945; Forestry Commission, 1921) the main part of British wood consumption was driven by imports and, thus, home-grown timber did not play a crucial role in this issue. Nevertheless, to date, no work in economic history has studied this problem in depth and so we will take some time to clarify it.

The available figures on British home-grown timber for this period are scant and somewhat disconcerting. For instance, Collins (1989) estimates for the first half of the $19^{\text {th }}$ century an annual harvest of around 3.3 million cubic meters. In a similar way, Mulhal (1903) reported an annual wood and timber harvest for Britain of around 3.9 million cubic meters in the 1880s. On the other hand, estimations made for the first decades of the $20^{\text {th }}$ century bring the figures down significantly, offering data that do not always fit well. For instance, the Forestry Sub Committee (Ministry of Reconstruction, 1917) reported an annual felling before the war of 1.2 million cubic meters, and the Forestry Commission (1942) a similar quantity for the 1920s. Those figures were assumed for some contemporary works (Zone and Sparkhawk, 1923). Nevertheless, Birch (1936) put the British annual timber harvest around 2.8 million cubic meters in the middle of the 1920s. So the questions are: how can we explain those ups and downs in estimations? In other words, how can we obtain a trustworthy calculation of home-grown wood and timber in the long run? 
TABLE $2^{2}$

AN ESTIMATION OF WOODED AREAS IN GREAT BRITAIN

\begin{tabular}{|c|c|c|c|c|c|}
\hline Coppice & $\begin{array}{l}1854 \\
\text { has. } \\
448275\end{array}$ & $\begin{array}{l}1905 \\
\text { has. } \\
233451\end{array}$ & $\begin{array}{l}1913 \\
\text { has. } \\
218935\end{array}$ & $\begin{array}{l}1924 \\
\text { has. } \\
213949\end{array}$ & $\begin{array}{l}1939 \\
\text { has. } \\
206411\end{array}$ \\
\hline Hardwood & n.d. & n.d. & 225984 & 179419 & 216730 \\
\hline Conifers & n.d. & n.d. & 342218 & 271702 & 543656 \\
\hline Mixed woods & & & 153806 & 122114 & 137146 \\
\hline Total high forest ${ }^{3}$ & 291246 & 707061 & 716739 & 573235 & 897531 \\
\hline "uneconomic"" & 140861 & 179145 & 178224 & 409986 & 210275 \\
\hline TOTAL & 880382 & 1119658 & 1113897 & 1125924 & 1314217 \\
\hline & $\%$ & $\%$ & $\%$ & $\%$ & $\%$ \\
\hline Coppice & 50.9 & 20.9 & 19.7 & 17.9 & 15.7 \\
\hline Hardwood & & & 20.3 & 15.0 & 16.5 \\
\hline Conifers & & & 30.7 & 22.7 & 41.4 \\
\hline Mixed woods & & & 13.8 & 10.2 & 10.4 \\
\hline Total high forest & 33.1 & 63.1 & 64.3 & 47.9 & 68.3 \\
\hline Non productive & 16.0 & 16.0 & 16.0 & 34.2 & 16.0 \\
\hline TOTAL & 100 & 100 & 100 & 100 & 100 \\
\hline
\end{tabular}

Some recent papers (Schandl and Schulz, 2002; Krausmann, Schandl and Sieferle 2008; Musel, 2009) have handled this problem, but so far as their objective was to calculate macro magnitudes (basically, the social metabolism of the British economy in the long run), in which wood and timber do not play a central role, they provide few details about methods. The only (perhaps quite obvious) clue they give is that "timber

\footnotetext{
${ }^{2}$ Figures for 1854 has been calculated using data provided by Collins (1989 and 2000) on woodlands of England and Wales, and adding figures for Scotland collected from the Statistical Abstract (1871); for 1913: Statistical Abstract (1913); for 1905: Board of Agriculture and Fisheries (1905); for 1924: Census of Production of 1924 (Forestry Commission, 1942); figures for 1939 have been calculated from data on State and private forestation between 1919 and 1939, provided by Robinson (1927) and Birch (1936).

${ }^{3}$ Composition of high forest by tree species: for 1924, data come from Forestry Commission (1942). The same percentage of species of 1924 has been calculated for 1913, assuming that between 1913 and 1924 there was no change due to the war and the post-war years. Data for 1939 have been calculated taking into account the percentages of tree species used in forestation operations in the second half of the $1920 \mathrm{~s}$ and the 1930s (Robinson, 1927; Birch, 1936)

4"Uneconomic" woodlands area: the Census of production of 1924 calculates $16 \%$ of forest surface unable to produce any economic return. This percentage has been extrapolated to the total wooded area for the remaining years. In 1924, this item also includes forest felled and devastated during the First World War (Forestry Commission, 1942).
} 
harvest before 1940 had to be assessed by extrapolating from the wooded area assuming typical values of productivity and making cross-checks with irregular reports about timber supply" (Schandl and Schulz, 2002). To do so, it is necessary to have data about wooded area and "typical productivity", which are not provided. Nevertheless, a review of the main literature and reports on forestry from the middle of the $19^{\text {th }}$ century can give us interesting clues on both questions.

Table 2 collects the available data from a variety of sources (see Table footnote for sources and assumptions) and allows us to set out some hypotheses about British forest evolution during this period ${ }^{5}$.

Total wooded area enjoyed significant growth from 1850 to 1913. This growth was different in different parts of the country (in fact, it is evident in Scotland and Wales but not in England) and it can be supposed to have taken place mainly from the $1880 \mathrm{~s}$, due to the agrarian crisis that stimulated the abandonment of some tilled areas. After the First World War, the increase continued, due mainly to the forestation works initiated by the State and followed also by some private owners in the 1920s and 1930s (Forestry Commission, 1921; Birch, 1936). This evolution is consistent with the trends seen in research on land use evolution (Best and Coppock, 1962; Department of Education and Science, 1966).

During the entire period, there were three significant changes in woodland composition. First, woodlands managed as coppice had a noticeable fall in the second half of the $19^{\text {th }}$ century. The crisis of rural industries related to wood (Chartres, 2000) and the failure of the hop crops (which used wooden poles) were the main reasons. Nevertheless, as Collins (1989 and 2000) states, coppice crops, far from disappearing, continued to play a remarkable role in rural economies, both for land fences and other rural works, and for forage for cattle. Although the coppice lost importance in many areas during the second half of the $19^{\text {th }}$ century, in others it remained essential until the 1930s (Tsouvalis, 2000, Tsouvalis and Watkins, 2000). Second, high forest areas grew until 1913, guided by the same forces that were driving the expansion of woodlands and the decrease of coppice. From then on, the high demand for timber during the First World War contributed to the devastation of an important area, which became nonproductive in subsequent years. Finally, it seems that there was a remarkable change in high forest composition. In the middle of the $19^{\text {th }}$ century, hardwood areas (mainly of oak, beech, and ash) were very probably dominant due to the traditional composition of English forests and also to the plantations (mainly of oak) dating from the second half of the $18^{\text {th }}$ century, which were closely related to demand from the Navy and shipbuilders (Forestry Commission, 1921; James, 1981). Conifers at this date were mainly in Scotland, where hardwood trees were rare (Forestry Commission, 1921). But from then onward, conifers also began to gain prominence within English woodlands. As the Forestry Sub Committee reported, it was a slow change, beginning in the 1880s with the gradual introduction of conifers in small scattered areas between hardwood and coppice (Ministry of Reconstruction, 1917). After the First World War, this trend was reinforced by the State forestry, which showed a clear preference for conifers. In fact, 96\% of the new plantations undertaken by the Forestry Commission from 1919 to 1936, were composed of conifers (Birch, 1936).

\footnotetext{
${ }^{5}$ For a discussion of problems with the calculation of woodland areas, see Cherry and Sheail (2000)
} 
To measure the effects that those changes in wooded area had on home timber production, it is necessary to approximate the physical yields of each kind of forest. Obviously, forestry yields depend on items like soil, climate and types of established rotations that we cannot ascertain for this period. In any case, we can handle certain data to approximate this problem, and it is summarized in Table 3. The main source of information is the work of Schlich (1903), who summarized the yields in physical terms for the main species of trees existing in Great Britain at the beginning of the $20^{\text {th }}$ century. He based his data on his own practice as a forester in many parts of England and Scotland and offered annual data for a complete turn of exploitation of the different species (for instance 70 years for larch and 130 years for oak) and also for the yields reached through thinning during the first years after plantation. In general terms, he stated, yields in Britain were much lower than those attained on the continent, due to the lack of appropriate forestry practices.

TABLE 3

ESTIMATES ANNUAL YIELDS FOR BRITISH FOREST

$\begin{array}{lcc}\text { Coppice } & 5-4.5 & \\ & & \\ \text { Larch } & 3.18 & \\ \text { Spruce } & 4.00 & 0.51 \\ \text { Scots pine } & 3.07 & \\ \text { Conifers average } & 3.41 & \\ & & \\ \text { Ash } & 1.71 & \\ \text { Beech } & 1.90 & \\ \text { Oak } & 1.79 & \\ \text { Harwood average } & 1.80 & \\ & & \\ \text { Average without coppice } & 2.61 & \\ \text { Average with coppice } & 3.1 & \\ \text { Source: Collins (1989) for coppice; Schlich (1903) for the remainder. }\end{array}$

Annual yields First thinnings

$5-4.5$

3.18

3.07

Conifers average $\quad 3.41$

1.71

1.79

Oak

This notion of the slow progress of British forestry before the First World War is shared by other authors (Simpson, 1903; Forbes, 1910; Stebbing, 1919) and allows us to assume that the yields of different species remained constant in Britain for the period 1850 to 1913. In fact, the main reason for the improvement of yields in other countries, such as Germany, was, according to these authors, the advances in forestry practice that were being demanded for Great Britain. This situation could have begun to change in the 1920s through the work of the Forestry Commission, but the new plantations established just after the war only began to have effects on yields twenty or thirty years later. Thus, it is difficult to imagine a significant change in yields before the end of the Second World War. Our hypothesis for high forest yields is, therefore, that they remained constant in term of species, although they could change in global terms depending on the composition of the total production. 
TABLE 4

AN ESTIMATION OF WOOD AND TIMBER HARVESTED IN BRITAIN

\begin{tabular}{|c|c|c|c|c|c|c|}
\hline & 1850 & 1905 & 1913 & 1914-1919 & 1924 & 1939 \\
\hline & $\mathrm{m}^{3}$ & $\mathrm{~m}^{3}$ & $\mathrm{~m}^{3}$ & $\mathrm{~m}^{3}$ & $\mathrm{~m}^{3}$ & $\mathrm{~m}^{3}$ \\
\hline Coppice & 2241376 & 1050531 & 985207 & n.d. & 962771 & 928847 \\
\hline Hardwood & & & 271181 & & 215303 & 390.113 \\
\hline Conifers & & & 1197762 & & 950958 & 1902795 \\
\hline Mixed woods & & & 399895 & & 317495 & 356580 \\
\hline $\begin{array}{l}\text { Total high } \\
\text { forest }\end{array}$ & 757239 & 1838358 & 1868838 & n.d. & 1483756 & 2649488 \\
\hline TOTAL & 2998614 & 2888890 & 2854046 & 6644504 & 2446528 & 3578336 \\
\hline & $\%$ & $\%$ & $\%$ & $\%$ & $\%$ & $\%$ \\
\hline Coppice & 74.7 & 36.4 & 34.5 & & 46.6 & 31.9 \\
\hline Hardwood & & & 9.5 & & 10.8 & 10.0 \\
\hline Conifers & & & 42.0 & & 31.9 & 48.9 \\
\hline Mixed woods & & & 14.0 & & 10.6 & 9.2 \\
\hline $\begin{array}{l}\text { Total high } \\
\text { forest }\end{array}$ & 25.3 & 63.6 & 65.5 & & 53.4 & 68.1 \\
\hline TOTAL & 100 & 100 & 100 & 100 & 100 & 100 \\
\hline
\end{tabular}

Source: Tables 1 and 2.

Regarding the yields of coppice, the only specific data found is that offered by Collins (1989) who, separating the profitability of the coppice, estimates a level of about 5 cubic meters per hectare per year during the first half of the $19^{\text {th }}$ century ${ }^{6}$. Other authors (Brown, 1861; James, 1981; Tsouvalis, 2000) also confirm the high profitability of a well-managed coppice crop in monetary terms, but only for areas situated near urban markets. On the other hand, Stebbing (1919) reports a fall in the profitability of coppice with standards from the end of the $19^{\text {th }}$ century, and especially after the war, due to the failure of the demand for some of its products. Taking all this into account, we assume a medium annual yield of $5 \mathrm{~m} 3 /$ ha in 1854 , and a small decline to $4.5 \mathrm{~m}^{3} / \mathrm{ha}$ from 1905 on. Those yields could be considered a little high, but assuming that level allows us to also capture the production of wood coming from trees and hedgerows outside the woodlands, a production that is known to have existed, but that we cannot estimate in any other way in the present state of knowledge. This assumption for coppice, single trees and hedgerows fits in quite well with data offered by Birch (1936) in 1924, and in general terms, provides medium yields of wooded areas for the whole period of $3.1 \mathrm{~m} 3 / \mathrm{ha}$. This figure is close to the assumptions of other authors, such as Warde (2007) and Krausmann, Schandl and Sieferle (2008), who present total yields for British forests as being around $3.3 \mathrm{~m}^{3} / \mathrm{ha}$.

\footnotetext{
${ }^{6}$ Collins offers higher yields for coppice, because he considers cubic feet of cordwood. Following Warde (2007) we have convert these yields to solid wood.
} 
Once we have an estimation of both wooded area and yields, we can combine them to arrive at an estimate of annual production. Table 4 shows the estimated data on wood and timber harvested in Great Britain in specific years, and includes an estimation of timber harvested during the First World War. According to Robinson (1927), Birch (1936) and to the report of the Forestry Commission (1921), it can be assumed that during the war the total harvest increased 2.5 fold annually over the level of 1913. All this data allows us to draw a first picture of the evolution of home-grown timber in the long run.

Excluding the war period, home-grown timber in Britain remained at a level between 2.9 to 3.5 million cubic meters during the years 1854 to 1939 , demonstrating little growth, but some interesting changes in composition and trends. From 1854 to 1913 there was a stagnation of total output, but an important change in composition. On the one hand, wood from coppice crops decreased, due mainly to the agrarian crisis and its consequences for the rural world (Tsouvalis, 2000). On the other hand, timber from high forest grew through an incipient specialization in conifers, which seems to follow the international trends in softwood use. Nevertheless, the limited advances in forestry reported by the experts (Schlich, 1903; Simpson, 1903; Forbes, 1910; Stebing, 1919) forestalled greater increases. The decline of imports during the First World War led to a substantial exploitation of domestic woodlands and brought on the devastation of a considerable area of forest. This devastation, joined with the decrease in coppice, brought the harvest of 1924 back to the level of 1854. So, most of the 1920s and 1930s were years of recovery to the pre-war level, but with a clear reinforcement of changes in timber composition. In fact, timber coming from high forest in 1939 represented $68 \%$ of the total harvest (just the reverse of the level of 1854, related to coppice) and conifers alone represented $48 \%$. Nevertheless, it was impossible for the new plantations established in those two decades to reach maturity until twenty or thirty years later, so total yields from high forest remained at low levels.

This estimation makes some risky assumptions, but it seems to be quite reliable. Perhaps its main advantage is that has taken into account a variety of data and ideas for single periods, in an attempt to fit it in a long-run vision. The result can be considered quite successful. For instance, the estimation tallies quite well with figures reported by Collins for around 1850 . On the other hand, for the beginning of the $20^{\text {th }}$ century and the period after the First World War, this estimation coincides almost exactly with data reported by Birch (1936) that are greater than those reported by official sources (Ministry of Reconstruction, 1917; Forestry Commission, 1942). However, it is probable that official statistics were reporting only the harvest of industrial timber coming from high forest (as they did after 1940, according to Schandl and Schulz, 2002). If this is true, the estimation also makes a good fit. In fact, the almost 1.5 million cubic meters reported here for high forest timber production in 1924 is not far away from the 1.6 million provided by official sources. On the other hand, if we calculate the yields of high forest timber related to the total wooded area, results also tally with estimations made by Forbes (1910) and Stebbing (1919). Finally, as we said before, the yields for total wood and timber consumption related to the total wooded area are not far removed from those assumed recently by other authors, such as Warde (2007) and Kraussman et al. (2008). 
To sum up, data calculated in this section show a growing wood consumption guided by imports. If at the middle of the19th Century, imports represented around the $50 \%$ of the consumption, in the 1930 s the percentage had dropped to around the $10 \%$.

\section{Some quantitative exercises.}

Chart 1 offer a reliable estimation of British wood consumption in the long run, taking into account both net imports and home-grown timber ${ }^{7}$. Chart 2 combines that data with British GDP, showing the IOU (Intensity of Use) of timber consumption.

\section{CHART 1}

ABSOLUTE TIMBER CONSUMPTION IN BRITAIN (cubic meters)

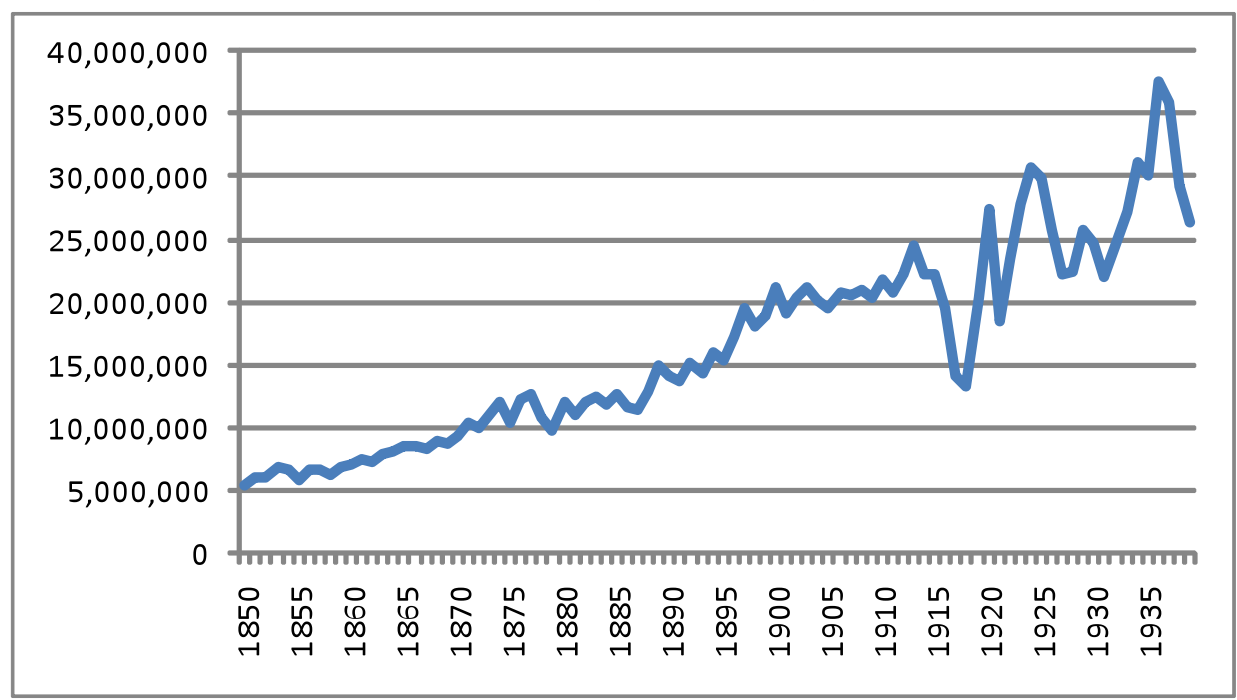

CHART 2

INTENSITY OF USE (IOU) OF TIMBER IN BRITAIN (cubic meters/GDP *100)

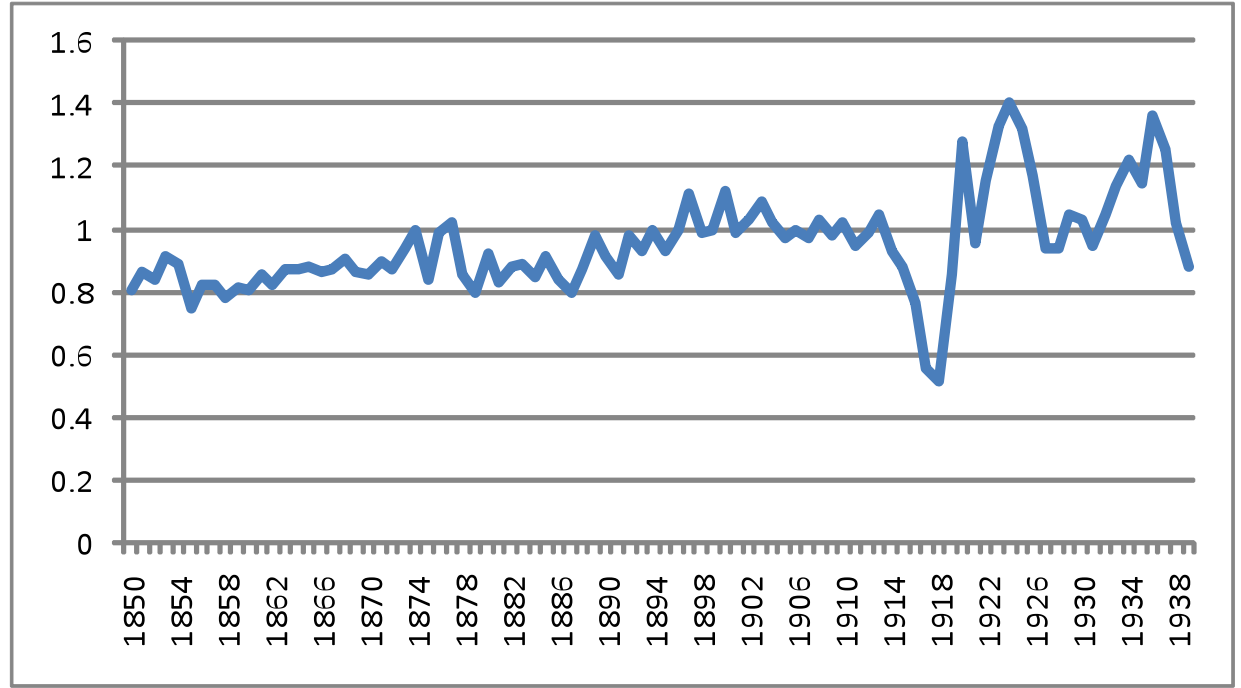

\footnotetext{
${ }^{7}$ Data for an annual wood and timber harvest series had been calculated interpolating figures between mark years, according to the medium annual growth from date to date.
} 
The two graphics clearly show the increase in wood consumption in both absolute and relative terms (IOU). Both also show two differentiated behaviors over time. While in the period between 1850 and 1913 absolute growth, as well as relative growth, had a relatively stable evolution, from wartime on we are faced with much more noticeable fluctuations, strong growth followed by times of decline. In any case, after the war, absolute as well as relative consumption was somewhat higher on average.

In order to analyze this evolution in more detail, we calculate a function of consumption that allows us to calibrate the elasticities of wood consumption (WC) with regard to GDP and also with regard to wood prices (WP) and those of a substitute material such as iron (IP) ${ }^{8}$. We have also included an index of building (IB) trying to capture the possible effects of building cycles on timber consumption ${ }^{9}$. The model is limited to the period from 1871 to 1936 , since data on iron prices for the prior period are not available. The variables of the model are in logarithms, so the estimations of the parameters of position are interpreted as elasticities. Following the results of previous works (Iriarte y Ayuda, 2008), our hypothesis is that wood consumption had a positive elasticity with regard to GDP. Regarding prices, we expected a negative sign for wood prices (an increase in its prices would halt the increase in consumption) and a positive sign for iron prices (an increase in the prices of this substitute material would contribute to more wood consumption), although we believe that the behavior of prices do not explain everything and have to be combined with others variables for an accurate explanation of consumption.

To avoid the problem of spurious regressions, we first analyzed the order of integration of the data series. To this end, we examined the graphics of the series, their correlograms $^{10}$, as well as the augmented Dickey-Fuller test (Dickey-Fuller, 1981). As all the series in this paper are series with a breaking trend function, we use the generalized least squares detrending method and we allow for three changes in both the level and slope of the trend function. So, to test the order of integration of the series we use the DF-GLS that tests the null hypothesis of a unit root, allowing breaks under both the null and the alternative hypotheses. To obtain the DF-GLS we use the programming algorithm described in Carrión-i-Silvestre et al. (2009). Because the DF test is generally known to have little power, we present also the results of the KPSS test of Kwiatkowski et al. (2001), that tests the null hypothesis of stationarity against the alternative of a unit root. Table 1 presents the results of the tests. We conclude that four of the series are stationary or trend stationary according to the DF-GLS test, at the $5 \%$ level of significance, and that the index of building, IB, and the iron price, IP, are integrated of order one, I(1), while all are stationary or trend stationary according to the KPSS test ${ }^{11}$.

\footnotetext{
${ }^{8}$ GDP data came from Maddison (2001). Prices of wood are import prices (cubic meter / price of total wood imports). Prices of iron came from Mitchell (1980).

${ }^{9}$ The index of building has been taken from Mitchell (1980).

${ }^{10}$ Graphs and correlograms are not shown here for reasons of space, but can be requested from the authors.

${ }^{11}$ For the results of the tests we have used the GAUSS program. For the KPSS test we have introduced the modification of the test proposed by Sul et al. (2005) that is known to improve the behaviour of the test in terms of size.
} 
TABLE 5: DF-GLS and KPSS tests

\begin{tabular}{|c|c|c|c|c|c|c|}
\hline Variables & DF-GLS & C.V. & & KPSS & C.V. & \\
\hline WC & -3.90 & -3.51 & $\mathrm{I}(0)$ & 0.11 & 0.15 & $\mathrm{I}(0)$ \\
\hline GDP & -3.82 & -3.46 & $\mathrm{I}(0)$ & 0.04 & 0.15 & $\mathrm{I}(0)$ \\
\hline WP & -3.65 & -3.59 & $\mathrm{I}(0)$ & 0.03 & 0.15 & $\mathrm{I}(0)$ \\
\hline IP & -3.06 & -3.87 & $\mathrm{I}(1)$ & 0.04 & 0.15 & $\mathrm{I}(0)$ \\
\hline IB & -3.08 & -3.78 & $\mathrm{I}(1)$ & 0.03 & 0.15 & $\mathrm{I}(0)$ \\
\hline
\end{tabular}

C.V.: Critical values at $5 \%$ significance level.

After that, given that the variables can be considered to be stationary ( with the exception of IB and IP, that, following the DF-GLS test, are not stationary, but they are following the results of the KPSS) we have estimated the following model, taking into account two dummy variables in order to test whether there is some structural change that we can appreciate from the graphs and in previous analysis of integration; F1, that takes value 1 in the years 1914-1922 and 0 in the rest, with the aim of measuring the effects of the First World War, and F2, that takes value 1 in the years 1923-1936 and 0 in the rest with the aim of measuring the changes after the First World War. In order to ensure the specification is correct, we test whether the residuals of the proposed model are also stationary. The most adequate model, according to Akaike's information criterion (AIC) and the Schwarz's Bayesian information criterion (SBIC), as well as the adjusted coefficient of determination, is the following ${ }^{12}$ :

TABLE 6: OLS estimation of the consumption function

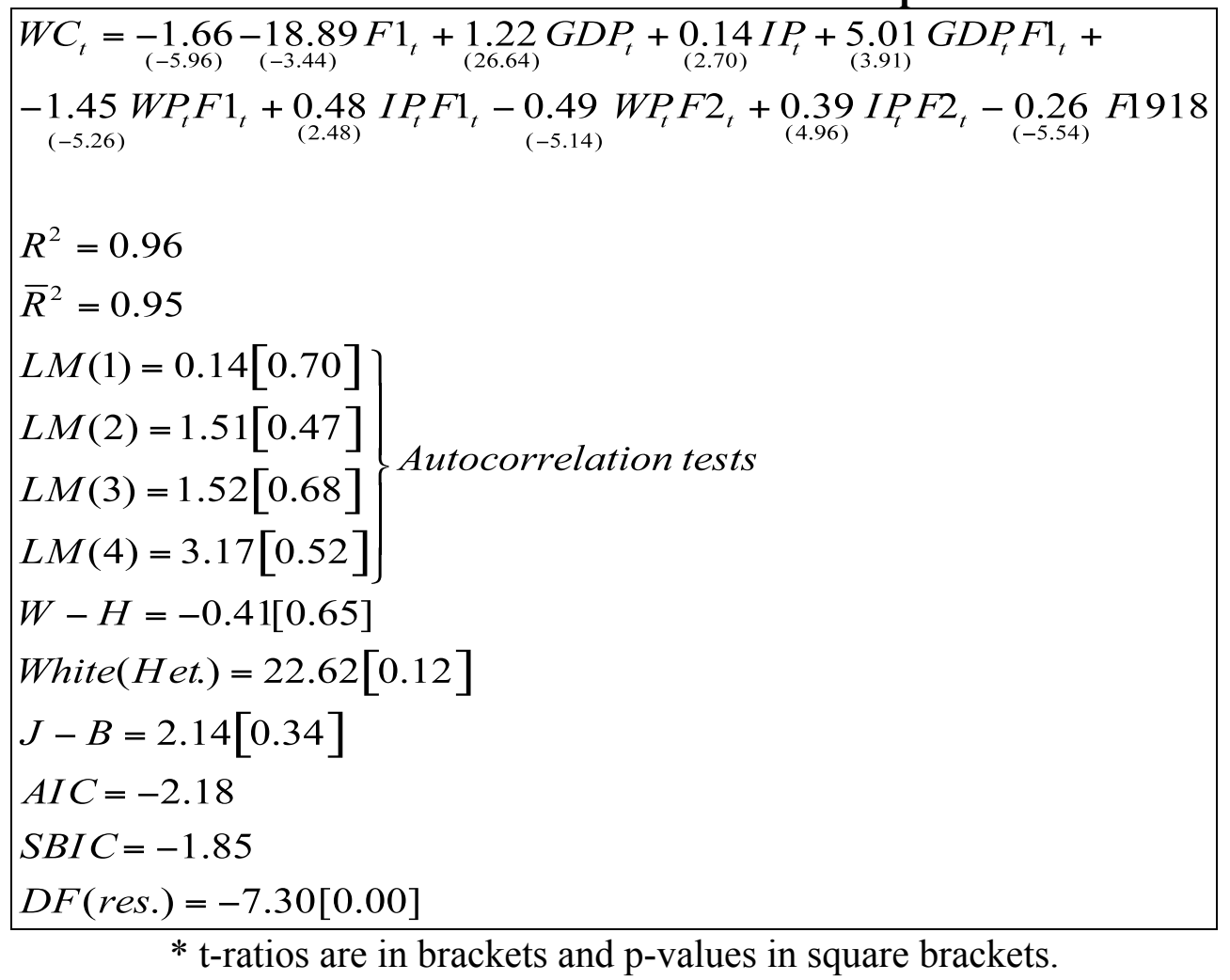

The variable IB is not in the model because it was not significant. All the parameters that appear in the model are significantly different from zero and display the expected

\footnotetext{
${ }^{12} \mathrm{We}$ also estimated a model with the relative price of timber with respect to iron, as an exogenous variable, but the model presented heteroskedasticity.
} 
sign. A dummy variable for the year 1918, F1918, has been introduced in the model because was detected as an outlier. As exogeneity is usually violated in these demand functions, we used the Wu-Haussman statistic, $\mathrm{W}-\mathrm{H}$, in order to test the exogeneity of the WP. Different lags of the Wood Price have been used as instrumental variables and in all the cases the exogeneity hypothesis has not been rejected even at high significance levels. The results of the $\mathrm{W}-\mathrm{H}$ test in the model corresponds to the case where the instrumental variable for WP was the first lag of the variable. The Breusch-Godfrey tests were applied in search of potential autocorrelation problems, LM(p), and the White test for possible heteroskedasticity. We conclude that the consumption function does not display autocorrelation and is homoskedastic at a significance level of 5 per cent. The estimated model is not a spurious relation, since the test to detect possible nonstationarity of the residual DF (res.) confirms the stationarity of the residuals.

TABLE 7: ESTIMATED ELASTICITIES OF WOOD CONSUMPTION

\begin{tabular}{lccc}
\hline & $1871-1913$ & $1914-1922$ & $1923-1936$ \\
\hline GDP & 1.22 & 6.23 & 1.22 \\
\hline WP & - & -1.50 & -0.49 \\
\hline IP & 0.14 & 0.59 & 0.53 \\
\hline
\end{tabular}

As we expected, wood consumption shows a positive elasticity with regard to GDP both before and after the war ${ }^{13}$. The new aspect, regarding the case of Spain previously studied, is that that elasticity is superior to the unit, highlighting the fact that wood consumption from the middle of the 19th century was especially linked to industrial development and, consequently, the growth in GDP in a heavily industrialized country like Great Britain, had a stronger pull on wood consumption than in the case of Spain. It is also worth noting that the IOU of wood consumption did not fail in Britain between 1871 and $1938^{14}$. Prices of timber, as well as of iron, show the expected sign, although the relevance varies considerably according to the period. Before the First World War, the evolution of wood prices is not significant, not even rising to a $10 \%$ significance level. Iron prices, on their part, show a reduced elasticity $(0.14 \%)$. That situation changed considerably during the war, when prices of raw materials skyrocketed and had a much more visible effect on consumption. During the 1920s and 1930s, the situation that obtained during the War remained, although at more moderate levels.

\section{Discussion}

The results presented in the previous sections allow us to establish some significant discussion points concerning economic growth, the use of natural resources, the substitution of materials, and technological change.

a) First, the observed growth of timber consumption, as well as positive and superior elasticity to the unit of consumption, with regard to GDP, allows us to take a fresh look at the process of energy transition and its results regarding the use of organic raw

\footnotetext{
${ }^{13}$ The strong increase in elasticity with respect to GDP in the period between1914-1922 is due as much to the drop in GDP from 1919 as to the strong increase in imports that occurred in the years immediately after the war.

${ }^{14}$ In Spain the energetic transition was followed of a drop in the total IOU of Wood (firewood plus wood as a raw material. Nevertheless, the IOU of Wood as a raw material tended to growth (Iriarte and Ayuda, 2008).
} 
materials. Undoubtedly, as Wrigley (1988 and 2010) pointed out the energy jump from firewood to coal was, at its base, a new form of economic growth that allowed the surpassing of limits on economies with an organic base. However, even in Great Britain, the country that first and most completely underwent that transition, the use of an organic raw material like wood continued to grow in the long run, along with the growth in GDP. It is possible that the collapse in the use o firewood for energetic purposes during the second half of the $18^{\text {th }}$ century and the first half of the $19^{\text {th }}$ were associated with a temporary drop in total wood consumption. In fact, Warde (2010) report a minimum total wood consumption of around 9 million cubic meters in 1720, including 4.4 million of cubic meters of tar \& pitch and ash, that is, a figure higher than those that we have calculated for 1850. Thus a more detailed research for that period is needed. But once the new industrial growth was consolidated in the middle of the $19^{\text {th }}$ century, wood consumption grew again, went beyond any figures reached in pre industrial era and got the highest level in history. It can be said, therefore, that in the long run the new growth based on fossil fuels stopped being dependent on wood for its energy uses, but continued to need that raw material as a complement to its own industrial growth. From this perspective, at least in the period between the middle of the $19^{\text {th }}$ century and the Second World War, it makes no sense to identify fossil-based economic growth with a process of dematerialization of the use of timber, since the latter did not occur in either absolute or relative terms.

b) Once we have a general view of wood consumption, the next step is to discuss what forces, and what uses of wood, were behind that growth and why wood was not substituted for other materials arising from industrial and technological development. The habitually accepted approach to explain the substitution of wood as an energy source and as raw material is based on scarcity, and price differentials of raw materials As Nathan Rosenberg (1973) put it "The Industrial Revolution in Britain essentially substituted cheap coal for wood as a source of fuel and power, and cheap and abundant iron for vanishing timber resources". In the case of the substitution of firewood for coal, the difference of prices is confirmed (Allen, 2009) and is accepted as a cause even by those authors who cast doubt on the existence of an authentic timber shortage in physical terms. Nevertheless, the data contributed by this work indicate that the substitution of wood as raw material was not as great as has been hitherto supposed

The evolution of the price of wood throughout the 19th century could be one of the elements that contributed to maintaining a high level of wood consumption. In fact, the available data suggests that the prices of wood imports to Britain were falling from the end of the Napoleonic Wars until the 1870s (Rackham, 1990), to become stabilized at a slight rise from that moment until the WWI (Stebbing, 1919), when wood, like other raw materials, strongly increased their prices (Forestry Commission, 1921). From there, prices of wood imports fell again during the inter-War years to levels lower than those recorded before the Great War. Thus, except for specific circumstances, reduction was the predominant tendency. That fall in price was due, as previously indicated, not only to the decrease in transport costs, but also to the fact that the international supply of wood was growing since new exporting countries had come into the market, and forest areas were exploited that had previously been untouched. From this perspective, it could be said that if, during the early modern period, the increase in timber prices had driven its substitution by coal as an energy source, their later reduction could contribute to its continued use as a raw material. Despite that, the elasticities shown in Table 7 suggest that prices of wood as well as a basic substitute such as iron, despite having 
influence, were not the determinant elements in the evolution of consumption. It seems necessary, therefore, to examine in detail the specific uses for which wood was substituted as raw material by other materials, as well as those other uses for which it continued to be used, in an attempt to find complementary explanations.

In the first case, the most obvious example is that of shipbuilding, a sector in which wood lost its prominence in the middle decades of the 19th Century. According to Evans (1982), in 1850, less than one-tenth of the British tonnage built was iron, but by 1875 , it was nine-tenths. That change had mainly to do with technical questions that gave the clear advantage to iron. For example, iron allowed the construction of boats with hulls that weighed less and, consequently could be increased in size and carrying capacity (Dyos and Aldcroft, 1969). Iron also gave greater integrity to the ships, due to the increased ease in joining the pieces, iron's greater strength, and to the advantages in incorporating modern machinery. In addition, given that many British ships spent a lot of time in tropical zones, iron also guaranteed there would be less deterioration of the hull due to environmental factors. (Evans, 1982). Wood was also replaced in many large structures, especially bridges; although wooden bridges on many railroad lines were built of wood until the middle of the 19th Century, as the size of these structures increased, iron was shown to be better adjusted to the new conditions of necessary resistance (Evans, 1982). Something similar occurred with machinery, due to the highly heterogeneous character of wood. As Haines (1990) states, not only is each species of tree unique, producing timber with a combination of qualities and properties unlike any other, every tree within a species can have different characteristics, depending on its conditions of growth. That heterogeneity and variability made wood difficult to use in a standard way for precision machinery and it was routinely avoided by mechanical engineers for their new projects and works.

So, what did wood continue to be used for? Information regarding this for the second half of the 19th century is scant, but the production figures gathered from the beginning of the 20th century provide some interesting clues. We have information on industries related to wood classified in various groups, according to their specific activities for 1907, 1924 and 1930. The figures do not provide systematic data of the quantities of wood used in physical terms, and it must be borne in mind that only a part of the wood consumed went to British industry, since another portion arrived from abroad already prepared for use in specific activities. This data, therefore, can serve only as an approximation of those kinds of products that continued to be made with wood. In a broad outline, we can distinguish three main types of activities. The first has to do with the sawmill industry, making pieces destined for different uses. A considerable part of their production (which in the period between 1924 and 1930 could be placed around $15 \%$ of wood consumption) was engaged in making pit-props for the collieries; another part, (around 11- 14\% of consumption for the same period) was sleepers for the railroads; a third part (around 55-60\% of consumption) was set aside for the creation of a variety of products for the construction of buildings (planks, battens, boards) and for interiors (floorings, mouldings, etc.). The second activity was the furniture and upholstery trade, including the construction of a wide range of objects, from furniture and cabinetry, to bedding and cushions; from drawing office furniture to theatre and cinema seating. Finally, the third activity had to do with the manufacture of containers for the transportation of merchandise, including a wide range of products such as crates, cases and barrels, boxes, and trunks. 
The production figures therefore give an idea of the main activities that sustained the growth in wood consumption, all of which were related in one way or another to modern economic growth. In fact, maintaining the new coal-based economy required wood for the support of such basic activities as the mines and the railway network. Both elements (mining and railways) were gaining in their production capacity and in the density of the network, which considerably increased wood consumption. On the other hand, some later innovations such as the telegraph, the telephone and electricity cable also depended on the timber poles to carry the wires. In all of these cases, it was necessary to renew the wood supports every so often, due to their deterioration, which brought new consumption over time.

The second element that sustained the growth in wood consumption over time had to do with the processes of urbanization, and, in general, with the building industry. It is known that modern economic growth was accompanied by considerable urban growth, which spurred a significant increase of the building trades. What has passed largely unnoticed, however, is the important part that wood continued to play in building construction. As Powel (1980) states for the 19th century "the applications of timber were very numerous and in many cases not susceptible of substitution with alternative materials". Roof structures, suspended floors, doors, cupboards and fittings, lintels, claddings, window frames and stairs, continued to be made from timber, as other temporary uses such as scaffolding, arch centering, and shoring. The light character of wood and the fact that it is relatively easy to work must have been fundamental reasons for its continued use. On the other hand, Rodger (1989) points out that there were few technological advances in the construction field during all of the 19th century, and that the dependence on traditional materials was very high. It must be said that something similar occurred during the inter-war period. According to Richardson and Aldcroft (1968), in the 1920s and 1930s a considerable portion of building costs were attributable to wood. That was also the main material in the making of furniture for public and private buildings. Although the economic history of the furniture industry has not been analyzed in detail, presumably the increase in per capita income was accompanied by an increase in the amount of furniture per household, which also contributed to the increase in wood consumption.

Finally, the transportation of merchandise related to the development of trade, associated at the same time to economic growth, was another sector in which wood was crucial. The re-usable character of wood containers makes it impossible to establish a direct relationship between the increase in trade and the production of wood containers, but it seems fairly evident that it must have been a positive relationship.

All this allows us to explain some of the forces that drove the growth in wood consumption. Before the First World War, there was a substitution of wood in uses for which other materials offered clear technical advantages, but not in many basic activities that continued to use wood, quite independently of prices. Nevertheless, following the Great War, other possibilities of substitution were opened up and thus prices of wood - and of alternative materials - played a more important role. Finally, it is worth noting that wood was used in a wide range of economic activities and that its consumption was not restricted to a single industry. This could explain, for instance, the absence of significance of the Index of Building (IB) used in our model. 
c) A third element that is worth noting is that of technological change associated with the use of wood. This is a forgotten aspect since normally, technical improvements have been considered as forces promoting the substitution of traditional raw materials. However, significant technological transformations also existed that affected wood that by improving its acquisition and its qualities had the effect of boosting its consumption. It is evident that, from the 19th century on, a whole series of innovations came into being affecting different phases of the process of harvesting and treating timber. There were, first of all, changes associated with the planting and rotations of trees (that which some authors began to call new forestry) the basic objective of which was the creation of a type of forest specifically designed to be able to cover the growing demand for wood generated by industrial economies. Given the peculiar characteristics of the forestry sector (long turns of exploitation and minimal intervention by man in the treegrowing process), the application of the principals of that new forestry was probably the only possible way to increase forest productivity. In the second place, there were some improvements in the manner of exploitation of forests that basically had to do with the improvement in tools to cut the timber. The appearance, for example, of the circular saw - powered first by steam and then by electricity - meant a fundamental change in the preparation of the material on the forest floor. And, above all, there was a series of improvements in the treatment of wood for modern purposes that can be characterized as an authentic process of industrialization of wood (Haines, 1990).

Wood treatment to improve durability and conditions had been a constant, at least from the Early Modern Era, when timber became essential for the fleets of the various European countries in expansion. But according to Haines (1990), the 19th century would bring new treatments directly related to industrialization and associated with the new uses of wood. The best-known were the application of chemicals to wood to extend its useful life (especially creosote), and the steam bending system that consisted of treating wood with steam to make the material more malleable. If chemical treatments were predominant in wood used outdoors (sleepers and poles), steam bending was used more for the manufacture of furniture and pieces that required greater curvatures (especially furniture). However, with the technologies of the second industrial revolution, treatments related to wood reached a higher degree of sophistication. Among these, the possibility of making plywood must be highlighted. Plywood is made from thin layers of wood that, when combined with certain types of glue, resulted in a new product more easily standardized for diverse purposes. The second great innovation was related to the production of paper by a chemical treatment to obtain wood pulp.

Although no specific research has been found on these innovations referring to wood in Britain, the impression is that, once this raw material no longer formed an essential part of ship building, the British economy no longer took an interest in this sector of investigation. Countries such as the USA, Canada, Germany and Sweden that had greater timber resources became technological leaders (Cohen, 1984; Dick, 1982). In fact, if we focus on wood pulp, it is evident that Britain required more and more of that product for its own production of paper. Nevertheless, the British economy did not develop that line of production (Shorter, 1981), but instead merely imported the necessary wood pulp (see the evolution of pulpwood in table 1). Nevertheless, British wood consumption was stimulated by innovations produced outside the country, contributing, no doubt, to its growth by increasing the uses for wood. 
We began this discussion by denying that British industrial development meant a "dematerialization" in wood consumption. Taking into account the technological innovations that we have mentioned, it can be said that the more suitable term for timber is trans-materialization, a word proposed by Labys (2004) for other materials. In fact, the use of wood in Britain throughout the 19th century, and during the inter-war period, passed through different stages, according to its uses. In some, as firewood, it had already lost its essential economic function as an energy source. In others, as in shipbuilding or construction of bridges, it was in a "declining stage"; and in others, (building, pit-props, sleepers and furniture) it reached a mature stage that provided wood with a long run of growing consumption. Finally, from the end of the 19th century, technological change applied to wood opened new possibilities for its use (plywood and wood pulp), positioning those new forms in an "initial introduction stage" which would not reach absolute maturity until after the Second World War.

d) Finally, the growth in British wood consumption showed also allows us to complement the idea developed by Krausmann, Schandl and Sieferle (2008) that considers "industrialization as a stepwise process of decoupling the supply of energy from land-related biomass" (p. 188). For those authors, the decoupling process was, at first, only partial since, despite coal substituting for firewood as an energy source, real economic growth - and the population growth it entailed - also meant an increase in the demand for food and feed that continued pressure on the land. What we can add, having measured the evolution of wood consumption, is that the growing demand for this raw material for uses related to industrial growth also had an effect in the same direction, and contributed to the increased pressure that economic growth exercised over land use. The British economy of the $19^{\text {th }}$ century did not have the capacity to increase food production or yields of wood to cover the growing demand, and thus had to resort in ever greater measure to imports. It is in this context of metabolic transition, in which we understand that the Corn Laws were also accompanied by the disappearance of timber duties in the middle of the 19th Century. In this sense, the decoupling of the new energy system from land use was only relative, that is, it was true only for domestic land, but not for land used abroad. It was in foreign countries where the linkages between growth and land continued to be evident, as far as food and feed were concerned, but also wood needed for economic growth was obtained from there. From this perspective, industrialization was not only a question of subterranean forests, in the sense used by Sieferele (2001); but also of foreign forests. It is notable that, to achieve the more than 35 million cubic meters of wood imported at the peak, in 1936, and given the yields obtained in wood, Britain had to devote more than 13 million hectares to wood production, an area almost ten-fold its actual woodlands, or $40 \%$ of the total area of the country.

\section{Concluding remarks}

At the end of the $17^{\text {th }}$ century, John Evelyn, one of the first Englishmen concerned with English forestry, advised his compatriots: "We had better be without gold than without timber". It was a time when wood played a crucial role in energy supply, and when timber was also essential to maintain the "wooden walls" that English war ships were considered to be. Two hundred years later, things were very different. Wood had lost its importance as a source of power and most of the fleet was made of iron. On the other hand, exports coming from the English industrial revolution were providing Britain with enormous amounts of "gold", part of which was used to obtain timber from 
all over the world. The timber age had gone, and the sources of power came from the subterranean forests represented by extensive coalfields. A new type of growth had begun and the economic role played by timber was beginning a process of change.

But that does not mean that that process were one of wood dematerialization. On the contrary - as we found in a previous work for the case of Spain - in Britain also, wood and timber consumption continued to grow, both in absolute and in relative terms, through industrialization. The difference was that, in Britain, the elasticity of wood consumption related to GDP was higher than in Spain and exceeded the unit, suggesting that the increase in wood consumption was closely related to the modern economic development, that is, the greater the industrial growth, the greater the elasticity of wood consumption. The three main drivers of that evolution were: 1) the decline of wood prices did not create the necessity to substitute wood in many industrial uses, at least before the First World War. After that, the evolution of the prices of wood and iron, and perhaps the increased opportunities to use other materials, meant that the elasticity of prices related to consumption was stronger. 2) The improvement in forestry at the international level, the introduction of new machinery for forest exploitation, and the industrialization of wood itself (changes in treatment, and development of new materials like plywood and wood pulp) opened new and broader possibilities for wood in new applications. 3) The fact that wood was crucial in a wide range of industrial uses (coal extraction, railroads, construction, furniture, transport, tools, paper making) was important for the increase in consumption, insofar as wood use could be partially substituted in some economic activities, but reinforced and extended in others, throughout a trans-materialization process.

Britain faced the increase in wood demand in a quite peculiar way. The yields of home- grown timber were stagnant before the First World War, while other countries were developing a new forestry through which they improved forest productivity for industrial purposes. On the contrary, British wood consumption relied almost totally on imports, especially after the repeal of timber duties. This situation began to change in the 1920s, when British governments tried to develop new plantation schemes in response to the great depletion of forests resulting from the exploitation of home- grown timber during the war. These changes did not advance very far before the onset of the Second World War. Moreover, it does not appear that the British economy invested in a significant amount of research on industrial wood innovations related to plywood or wood pulp. Thus, in the 1920s and 1930s, British dependence on wood and wood pulp coming from abroad actually grew. In other words, the decoupling of economic growth from land use, was true at the domestic level, but not on the global scene. Without doubt, British economic development was to a great extent focussed on the subterranean forest, but simultaneously supported large tracts of foreign forest.

\section{Acknowledgements}

The authors wish to thank the Spanish Department of Education-MICIN projects ECO2009-07936, ECO2009-07796, HAR2009-09700 and the Department of Science, Technology and Universities of the Aragonese Government, consolidated research group of " Econometric Model Selection" (DGA-S21) and consolidated research group of "Agro- Food System History" (DGA-S27) for financial support. A previous version of this paper was presented at "First Quantitative Agricultural and Natural Resources History Conference (Agricliometrics)": Zaragoza, 2-4 June 2011. 


\section{References}

BOARD OF AGRICULTURE AND FISHERIES (1905) Agricultural Returns in Great Britain, Her Majesty's Stationary Office, London.

ALBION, R.G. (1926) Forests and Sea Power, Harvard.

ALLEN, R. C. (2009) The British industrial Revolution in Global Perspective, Cambridge University Press, Cambridge.

ÁSTRÖM, S.E. (1987) "Northeastern Europe's Timber Trade Between The Napoleonic and Crimean Wars: A Preliminary Survey", The Scandinavian Economic History Review, 35, p. 170-177.

BEST R. H. and COPPOCK, J.T. (1962) The changing use of land in Britain, Faber and Faber, London.

BIRCH, T. W. (1936) The afforestation of Britain, Economic Geography, 12-1, 2-27.

BROWN, J. (1861) The forester. A practical treatise on the planting, rearing, and general management of forest trees, William Blackwood and soons, Edinburgh census of production, 1924.

CARRIÓN-I-SILVESTRE, J.L., Kim, D. and Perron, P. (2009) GLS-Based unit root tests with multiple structural breaks under both the null and alternative hypotheses. Econometric Theory, 25, 1754-1792.

CHARTRES, J. (2000) "Rural industries and manufacturing", in COLLINS, E.J.T. The Agrarian History of England and Wales, VII, 1850-1914, CUP, Cambridge, pp. 1101-1149.

CHERRY, G.E. and SHEAIL, J. (2000) "Woodlands", in COLLINS, E.J.T. The Agrarian History of England and Wales, VII, 1850-1914, CUP, Cambridge, pp. 1101-1149.

COHEN, A. (1987) Factor substitution and induced innovation in north American kraft pulping: 1914-1940, Explorations in Economic History, 24, PP. 197-217

COLLINS, E.J.T. (1989) "The coppice and underwood trades", in MINGAY, G.E. (1989) The agrarian history of England and Wales, Vol VI, 1750-1850, CUP, Cambridge, pp. 484-501.

COLLINS, E.J.T. (2000) "Rural and agricultural change" in COLLINS, E.J.T. The Agrarian History of England and Wales, VII, 1850-1914, CUP, Cambridge, p. 72223.

DEPARTAMENT OF EDUCATION AND SCIENCE (1966) Report of the Land use Study Group. Forestry, agriculture and the multiple use of rural land, Her's Majesty Stationery Office, London.

DICK, T.J.O. (1982) Canadian Newsprint, 1913-1930: National Policies and the North American Economy, The Journal of Economic History, 42, 659-687

DICKEY, D.A., FULLER, W.A. (1981) Likelihood ratio tests for autoregressive time series with a unit root, Econometrica 49, 1057-1072.

DYOS, H. J. and ALDCROFT, D.H. (1969) British transport. An economic survey from the seventeenth century to the twentieth, Leicester University Press, Surrey.

EVANS, F. T. (1982), Wood Since the Industrial Revolution: a Strategic Retreat?, History of the Technology 7, pp. 37-55.

FISCHER-KOWALSKI, M. HABERL, H. (1993) Metabolism and colonization modes of production and the physical exchange between societies and nature. Innovation in Social Sciences Research 6, 415-442. 
FITZGERALD, R. AND GRENIER, J. (1992) Timber. A centenary history of the Timber Trade Federation, 1892-1992, Batsford Ltd., London.

FORBES, A.C. (1910) The development of British Forestry, Arnold, London

FORESTRY BILL (1919), Parliamentary Papers, 156.

FORESTRY COMMISSION (1921) First annual report of the Forestry Commissioners, Parliamentary Papers, 128, 1921.

FORESTRY COMMISSION (1942) Post-war forest policy report by H.M. Forestry Commissioners, Parliamentary Papers, Cmd. 6447, 1942-43.

GAUNITZ, S. (1969) Forest resource and forest industry in Northern Sweden 19001939, Economy and History, XII, p. 43.

HAINES, Ch. M. (1990) The industrialization of wood: The transformation of a material, $\mathrm{PhD}$ Dissertation, University of Delawere.

IRIARTE-GOÑI, I. and AYUDA, M. I. (2008) Wood and industrialization Evidence and hypotheses from the case of Spain, 1860-1935, Ecological Economics, 65, 177-186.

JAMES N.G.D. (1981) A History of English Forestry, Basil Blackwel, Oxford.

JEFFERIES, Richard (1945) The wood from the trees, The pilot press, London.

KRAUSMANN, F SCHANDL H., SIEFERLE R. P. (2008), Socio-ecological regime transitions in Austria and the United Kingdom, Ecological Economics, 65, 187-201.

KRAUSMANN, F. SCHANDL, H. and SCHULZ, N.B. (2003): Long-term industrial transformation. A Comparative Study on the Development of Social Metabolism and Land Use in Austria and the United Kingdom 1830-2000. Social Ecology Working Paper, vol. 70. Krausmann, Schandl, and Schulz, 2003.

KWIATKOWSKI D, PHILLPS P.C.B., SCHMIDT P., and SHIN Y (1992) Testing the null hypothesis of stationarity against the alternative of a unit root, Journal of Econometrics, 54, 159-178.

LABYS, W.C. (2004) Dematerialization and transmaterialization: what have we learned? 1. Research Paper Series, WVU Regional Research Institute.

LATHAM, b. (1957) Timber, Its development and distribution. A historical Survey, George G. Harrap, London.

LOWER, A.L.M. (1973) Great Britain's wood yard. British America and the timber trade, 1763-1867, McGill-Queen's University Press, London.

MADDISON, A. (2001) The World Economy: A Millennial Perspective, OECD Development Centre, Paris.

MINISTRY OF RECONSTRUCTION (1917), Forestry Sub-Committee. Final report, Parliamentary papers, Cd. 8881, 1917-18.

MITCHELL, B. R. (1980) British historical Statistics, CUP, Cambridge, 186-187.

MULHALL, Michael G. (1903) The dictionary of Statistics, Routledge, London.

MUSEL, A. (2009) Human appropriation of net primary production in the United Kingdom, 1800-2000 Changes in society's impact on ecological energy flows during the agrarian-industrial transition, Ecological Economics, 69, 270-281.

ROSENBERG, N. (1973) Innovative Responses to Materials Shortages, The American Economic Review, Vol. 63, No. 2, pp. 111-118.

POTTER, J. (1955) The British Timber duties 1815-1860, Economica, New Series, 22, $86,122-136$.

POWEL, C.G. (1980) An economic history of the British building industry, 1815-1979, The Architectural Press, London.

RACKHAM, O (1990) Trees and woodland in the British landscape, Dent and sons, London. 
RICHARDSON, H.W. and ALDCROFT, D.H. (1968) Building in the British economy between the wars, Allen \& Unwin, London.

ROBINSON, R.L. (1927) British Forestry, Forestry, 1-5.

RODGER, R. (1989) Housing in urban Britain, 1870-1914: Class, capitalism and construction, MacMillan, London.

SCHANDL, H. and SCHULZ, N. (2002) Changes in the United Kingdom's natural relations in terms of society's metabolism and land-use from 1850 to the present day, Ecological Economics 41, 203-221.

SCHLICH, W. (1904) Forestry in the United Kingdom, Bradbury, Agnew \& Co, London.

SHORTER, A.H. (1971) Paper making in the British isles. A historical and geographical study, David and Charles, Newton.

SIEFERLE, R.P. (2001) The Subterranean Forest: Energy systems and the industrial revolution. The White Horse Press, Cambridge.

SIMPSON, J. (1903) The new forestry or the continental system adapted to British woodlands and game preservation, Pawson and Brailsford, Sheffield.

SIMPSON, J. (1909) British woods and their owners, Paulson \& Brailsford, Sheffield Simpson.

SÖDERLUND, E.F. (1953) Swedish Timber Exports 1859-1950. A History of the Swedish Timber Trade, Stokholm, The Swedish Wood Exporters association.

STATISTICAL ABSTRACT (1871), Her Majesty's Stationary Office, London

STATISTICAL ABSTRACT (1913), Her Majesty's Stationary Office, London

STEBBING, E.P. (1919) Commercial forestry in Britain: its decline and revival, London : J. Murray.

SUL, D, PHILLIPS, P.C.B. and CHOI, C.-Y. (2005) Prewhitening Bias in HAC Estimation, Oxford Bulletin of Economics and Statistics, 67, 517-546.

TSOUVALIS, J. (2000) A Critical Geography of Britain's State Forests, Oxford University Press, Oxford.

TSOUVALIS, J. and WATKINS, Ch. (2000) Imagining and creating forest in Britain, in AGNOLETTI, M. and ANDERSON, Forest History, IUFRO research series, 2, Cabi, Oxon, pp. 371-387.

WARDE, P. (2006a) Ecology, Economy and State Formation in Early Modern Germany, Cambridge University Press, Cambridge.

WARDE, P. (2006b) Fears of wood shortage and the reality of the woodlands in Europe, c. 1450-1850, History Workshop Journal, 62, 1, 29-57.

WARDE (2010) Wood and wood products in the English economy, c. 1550-1750, Manuscript.

WARDE, P. (2007) Energy consumption in England and Wales, 1560-2000, Consiglio Nazionale delle Ricerche, Napoli.

WRIGLEY, E. A. (1988) Continuity, chance and change. The Characte of the Industrial Revolution in England. Cambridge University Press, Cambridge.

WRIGLEY, E. A. (2010) Energy and the English Industrial Revolution, Cambridge University Press, Cambridge.

ZAPATA, S. (2001) La madera en España, c.1850-c.1950. Un primer esbozo, Revista de Historia Económica XIX (2), 287-343.

ZON R. and SPARHAWK, W.N. (1923) Forest resources of the world, McGaw Hill, London. 